\title{
Post-Perestroika Ideologemes Survey (Based on the Newspaper "Izvestiya"
}

\author{
Azaliya R. Gizatullina*1, Milena I. Gumerova ${ }^{2}$, Tatyana Y. Vinogradova ${ }^{3}$, Mikhail A. Grachev ${ }^{4}$ \\ 1, 2, 3 Kazan (Volga) Federal University, Leo Tolstoy Institute of Philology and Intercultural Communication, \\ ${ }^{4}$ Linguistics University of Nizhny Novgorod, Department of Russian Philology, \\ Foreign Literature and Intercultural Communication. \\ E-mail: azaliya_rysh@mail.ru,Contact: 89274205223
}

Received: 21st October 2017 Accepted: 16th November 2017, Published: 31st December 2017

\begin{abstract}
The ability of linguistic units to generate new connotative and associative meanings (that is, intentionality) is especially relevant for political rhetoric, the function of which is to influence an audience as a rule. A created semantic field requires a detailed analysis both from the point of view of political science and from the point of view of linguistics, since ideologemes are the phenomenon of political reality and a language fact simultaneously.

The study is devoted to the understanding of the postperestroika period ideological system. In the framework of the political-journalistic discourse (based on the material of the daily "Izvestia" issues in 1992) eight thematic groups of post-perestroika period ideologemes were singled out by the method of continuous sampling (the total number of ideologeme uses was 1658 units). Ideological nature, repeatability and evaluation were referred to the obligatory signs of an ideologeme (understood as the ability to influence an existing picture of the world).

The study used descriptive method, the method of continuous sampling of material, quantitative methods and the method of semantic-cognitive analysis. The systematization of the selected groups of ideologemes is performed on various grounds (from the point of view of relevance / irrelevance in the ideological picture of the world under consideration, taking into account the pragmatic component, in terms of use and understanding by native speakers). The significance of the ideological units under consideration is characterized and their importance in the analyzed period is found using the material of the newspaper "Izvestia".

The leading "democratic" ideologems did not form the basis of modern political discourse, as the promises of a "golden" democratic future were not justified. The results of the research can be applied for further theoretical understanding of the post-Soviet political myth.
\end{abstract}

Keywords: Ideologeme; Post-Perestroika; PoliticalPublicistic Discourse, Newspaper "Izvestia"; Opposition "ours - theirs"; "Democracy"; "the USSR"; "Gaidaronomika"; Political Myth.

\section{Introduction}

Linguistic sovetologists believe that the year 1992 is considered as the starting point of modern political language research beginning [Budaev, Chudinov 2008]. This is the end of perestroika and the beginning of a new era for a former totalitarian country with a planned economy. The destruction of the Soviet myth led to the change in social values to the opposite ones, previously viewed as "hostile". At the same time, there was the process of new foundations modeling for Russians worldview (within the language level - at the expense of units containing an ideological component), and the media played a significant role in this.

Thus, it becomes urgent to study the technologies of information and political management by public consciousness (because at the present stage the struggle for political power is carried out mainly in the aspect of information warfare) to develop the methods of confrontation. One of the fundamental tools for linguistic picture of the world transformation is ideologemes (representing the central nominations of a mythologeme [Vepreva, Shadrina 2006: 125]).

A number of publications is devoted to the study of political, political and journalistic discourse [Harkova, Shigapova 2014; Sheigal 2000; Shemshurenko, Shafigullina 2015; Van Dijk 1998; Wodak 1989, et al.], in particular, concerning the perestroika, post-Soviet discourse [Dunn 1995; Koteyko 2014; Political Discourse 1998; Ryazanova-Clarke 2008; Shaposhnikov 1998, etc.], an ideological content of political discourse [Erol 1993; Guseinov 2003; Malysheva 2009; Robinson 1995 et al.].

This work is devoted to the understanding of the ideological system of the initial post-perestroika stage.

\section{Materials and Methods}

The study used the descriptive method, the method of continuous sampling of material, the quantitative methods and the method of semantic-cognitive analysis.

By the method of continuous sampling ( 281 issues), the key groups of the post-perestroika period ideologemes were revealed in political and journalistic discourse on the basis of the national Soviet and Russian socialpolitical and business daily newspaper "Izvestia" of 1992 [Izvestia, 1992], positioning itself as an independent publication, in which both opinions "under the control" of the state power are present, as well as 
oppositional statements, which, in our opinion, gives a more comprehensive and objective picture of the political-journalistic discourse.

Following E.G. Malysheva and E.A. Nakhimova, we turn to the linguistic-cognitive approach of ideologeme nature understanding [Malysheva 2009; Nakhimova 2011], we propose the following definition: ideologeme is a mental unit that includes an ideological component (which is intended to form a given idea of political reality), and which is realized and actualized in a text and a discourse usually by a word or a stable phrase. The obligatory signs of ideologeme include: 1) ideological nature (the ability to determine the motivation of actions, to form a world image) [Klushina 2014: 56-57]; 2) evaluational nature [Vepreva, Shadrina 2006: 122; Zhuravlev 2004: 28] and 3) repeatability, the actualization within a discourse [Zhuravlev 2004: 21].

We selected eight most important thematic groups ${ }^{1}$ ideologemes (from the point of view of frequency and relevance in the political discourse under discussion) (see "Table 1"):

Table 1 The Total Number of Ideological uses During the Period under Study was 1658 units.

\begin{tabular}{|l|l|l|}
\hline Ideologeme Group Name & $\begin{array}{l}\text { Number of uses in the } \\
\text { newspaper «Izvestia» during } \\
\mathbf{1 9 9 2}\end{array}$ & $\begin{array}{l}\text { The share of uses in the } \\
\text { newspaper «Izvestia» during } \\
\mathbf{1 9 9 2}\end{array}$ \\
\hline Democracy & 367 & $22,1 \%$ \\
\hline Gaidaronomika & 345 & $20,8 \%$ \\
\hline the USSR & 253 & $15,3 \%$ \\
\hline Yeltsin & 244 & $14,7 \%$ \\
\hline Disintegration ideologemes & 205 & $12,4 \%$ \\
\hline Integration ideologemes & 122 & $7,4 \%$ \\
\hline The Crimean Issue & 89 & $5,4 \%$ \\
\hline Orthodox Church and State & 33 & $1,9 \%$ \\
\hline
\end{tabular}

\section{Results}

Within the framework of our research, we found it logical to address the classification of ideologemes on several grounds (based on the systematization proposed in [Malysheva 2009: 37]): 1) from the point of view of relevance/irrelevance in the ideological picture of the world under study; 2) taking into account the pragmatic component (axiological orientation); 3) from the point of view of the sphere of use and the understanding by native speakers.

1. From the point of view of relevance/irrelevance in the ideological picture of the world (1992), the groups of ideologemes are distributed as follows (see "Table 2"):

Table 2

\begin{tabular}{|l|l|l|}
\hline $\begin{array}{l}\text { Name of Ideologeme } \\
\text { Group }\end{array}$ & $\begin{array}{l}\text { Types from the Point of } \\
\text { View of their Relevance }\end{array}$ & Comment \\
\hline Democracy & Universal Ideologemes & $\begin{array}{l}\text { Universal ideologemes include "actualized ones in } \\
\text { the ideological picture of the world, regardless of a } \\
\text { social and political system and the views of any } \\
\text { political elite" [Malysheva 2009: 39]. } \\
\text { At the same time, in the course of post-Soviet } \\
\text { political rhetoric, during the definition of the concept } \\
\text { "democracy", the value component (with the } \\
\text { connotative value of opposition to the party system } \\
\text { of the CPSU Central Committee) begins to be } \\
\text { accentuated, rather than class orientation, that points } \\
\text { to the changes of this concept perception in society. }\end{array}$ \\
\hline Gaidaronomika & $\begin{array}{l}\text { They are ideologemes-historicisms for the present } \\
\text { time; they include the ideologeme-anthroponym } \\
\text { "Gaidar". }\end{array}$ \\
\hline the USSR & New ideologemes & $\begin{array}{l}\text { There was the revival of the deactualized group of } \\
\text { ideologemes in a negative sense due to new } \\
\text { ideological orientation. For the present time they are } \\
\text { ideologemes-historicisms. }\end{array}$ \\
\hline Yeltsin & $\begin{array}{l}\text { For the present time they are ideologemes- } \\
\text { historicisms. }\end{array}$ \\
\hline
\end{tabular}




\begin{tabular}{|l|l|l|}
\hline Integration ideologemes & Universal ideologemes & $\begin{array}{l}\text { The group of ideologemes is connected with the } \\
\text { opposition "ours - theirs". }\end{array}$ \\
\hline The Crimean Issue & Reactivated ideologemes & Connected with the opposition "ours - theirs". \\
\hline Orthodox Church and State & Reactivated ideologemes & $\begin{array}{l}\text { The revival of deactualized ideologemes with the } \\
\text { filling by new content. }\end{array}$ \\
\hline
\end{tabular}

On the basis of relevance, the classification of ideologemes allows us to identify the meaningful ideologemes for a particular period (in our case, postperestroika), as well as the ideologemes relevant for a long time, which allows us to discover the semantic cognitive transformations that take place with them.

2. Taking into account the pragmatic component, ideologemes are defined by the parameter of an estimated potential, from our point of view, underlying the ideologization of language units: here the ideologemes with positive, negative and mixed axiological modus are distinguished (which assumes the mode fluctuations from positive to ambiguous and negative [Malysheva 2009: 38]). In order to determine mode nature, we examined the connotations in the groups of ideologemes, acquired in the relevant contexts of the newspaper "Izvestia" (see "Table 3"):

Table 3

\begin{tabular}{|l|l|l|l|}
\hline Ideologeme Group Name & Positive Connotation & Negative Connotation & Mixed Connotation \\
\hline Democracy & $57 \%$ & $23 \%$ & $20 \%$ \\
\hline Gaidaromics & $19,1 \%$ & $36,5 \%$ & $44,4 \%$ \\
\hline the USSR & $1,6 \%$ & $98 \%$ & $0,4 \%$ \\
\hline Yeltsin & $84,4 \%$ & $12,7 \%$ & $2,9 \%$ \\
\hline Disintegration ideologemes & $100 \%$ & - & - \\
\hline Integration ideologemes & $95 \%$ & $5 \%$ & - \\
\hline The Crimean Issue & $5,6 \%$ & $92,1 \%$ & $2,3 \%$ \\
\hline Orthodox Church and State & $87,9 \%$ & $12,1 \%$ & - \\
& & & \\
\hline
\end{tabular}

As is evident from the table, the analyzed ideologemes are allocated in the newspaper "Izvestia" with various estimates. Moreover, the disintegration ideologies have absolutely positive (100\% use) appraisal and are characterized by positive axiological modus, the rest ones are characterized by a mixed axiological mode: the ideologeme "the USSR" has almost completely negative evaluation ( $98 \%$ of use), the ideologeme "Yeltsin" has a positive evaluation in the vast majority of uses $(84.4 \%)$. These are the significant indicators of those processes that occurred during the described period: the differentiation of the concepts "the USSR" and "Russia" with a negative assessment of the events happening in the USSR. A scheme is emerging for the creation of a new political myth: from the dark party past to a brighter future, led by a strong democratic leader, Boris Yeltsin.

Taking into account the axiological orientation (evaluation) expressed by ideologemes, it is also necessary to take into account the classification made with respect to mythologemes in [Sheigal 2000: 195198]. In accordance with it, we differentiate ideologemes (see "Table 4"), which affirm positive values from the standpoint of an acting ideology (an ideal ideologeme), and the ideologemes that personify the evil force (ideologemes nightmares). This division is conditioned to the fact that ideology is based on oppositions, the most significant of which is "ours theirs" (and which is one of the oldest in human society [Schuklina 2014: 640]), and the ideologemes cumulate this attitude depending on a political situation.

Table 4

\begin{tabular}{|l|l|}
\hline Ideologeme Group Name & Axiological Orientation \\
\hline Democracy & Ideal ideologemes \\
\hline Gaidaromics & Ambivalent axiological orientation \\
\hline the USSR & Ideologemes nightmares \\
\hline Yeltsin & Ideal ideologemes \\
\hline Disintegration ideologemes & Ideologemes nightmares \\
\hline Integration ideologemes & Ideal ideologemes \\
\hline The Crimean Issue & Ideologemes nightmares \\
\hline Orthodox Church and State & Ideal ideologemes \\
\hline
\end{tabular}


Let us confirm the mentioned above by the analysis of such ideologeme thematic groups as "Democracy", "the USSR" and " Gaidaronomika".

From the point of view of axiological orientation, the group "Democracy" refers to the ideal ideologemes. At that time this group defined the nodal orientation of the opposition "ours" (democracy) - "theirs" (USSR), its semantics is also closely related to the concept of freedom: "Blue, white, red are the colors of freedom and democracy. Our flags symbolize democratic values, for which Russia and America managed to unite finally in a democratic partnership" (Izv. 992,139,06) ${ }^{3}$; "The CPSU prohibition was a decisive breakthrough in the struggle for freedom, justice and democracy" (Izv.1992,166,07).

A large number of the ideologemes of this group is explained by the destruction of the Soviet myth and the need to establish a new democratic mythology in the public consciousness. The democratic myth grew out of the totalitarian one, but it has also destroyed it: "The CPSU Party is the midwife of democracy in Russia" (Izv.1992,157,07); "There was a unique political situation in Russia and around it, developing in the direction of genuine democratization, in the direction of loosening the foundations of the parasitic nomenclatural system" (Izv.1992,239,10).

In this regard, the connotative semantics of the ideologeme "Democracy" in Russia turned out to be different from the generally accepted one. Traditionally, democracy means the form of political system in which the supreme power belongs to people, in the post-Soviet discourse democracy is also the opposition to the enemy authority of CPSU Central Committee: "The CPSU, its charter and activities violated the basic principles of democracy and international law for 70 years" (Izv.1992,166,07).

Meanwhile, often the ideologemes of the described group are addressed to the future. This was facilitated by the general crisis situation, which required the belief in a democratic "bright future" in return for the Soviet one: "The establishing of democracy requires a lot of work and struggle" (Izv.1992,177,08).

The group of ideologemes "the USSR" in the postSoviet space lost its former positive value and acquired an extremely negative one (ideologeme-nightmare) due to new ideologemes that affirm the image of the USSR as an absolute enemy. The ideologemes of the group being characterized was aimed at the desacralization of the Soviet and the establishment of the democratic myth: "The Soviet Union is an evil empire, a bloody era, an inhuman order and moral lawlessness"; "The dark period of our past, fears and humiliations are behind" (Izv.1992,01,01); "Any step back to the tyranny of the past will be a tragic mistake" (Izv.1992,172,07).

The ideologemes-anthroponyms of the Soviet leadership began to be perceived negatively in this group. They were moved to the area of "theirs": "Khrushchev is the Crimean voluntarist" (Izv.1992,162,07), etc.

2273
The group of ideologemes "Gaidaromics" marked the turn to Western values, namely - to economic freedom in market economy conditions. Since the post-Soviet myth was in the process of becoming (1992), the ideology of this group has a clear phenomenon of the denoter semantic uncertainty. Perhaps, it was best indicated in the metaphor "Russian roulette of the Russian reform" (Izv.1992,23,01). Meanwhile, the bad economic situation, the lack of practice of economic freedom, determined the ambivalent axiological orientation of this group of ideologemes: "By the end of the year, the economy, like a beaten and a driven horse, collapsed" (Izv.1992,27,02); "Does the capital meet the morning of market freedom without bread at all?" (Izv.1992,02,01). Subsequently, the group of ideologemes proclaiming the freedom of market relations became one of the post-Soviet myth components.

3. From the point of view of the sphere of use and the understanding by the native speakers of the language, the considered groups of ideologemes were distributed as follows (see "Table 3"): 1) commonly used, understood in different ways ("Democracy", "Yeltsin", "Crimean Issue", "Gaidaronomika", "the USSR", "integration ideolodemes", "Orthodox Church and State"); 2) commonly used, understood in the same way ("disintegration ideolodemes").

\section{Discussion}

As was noted in introduction, we share the position that ideologemes are the basis for the development of mythological consciousness, one of the features of which is a clear division into "ours" and "theirs" and influence the transformation of the political world linguistic picture.

One of the most important signs of ideology is the appraisal, and it can vary depending on a political situation.

For example, one of the leaders in the post-Soviet discourse was the group of "Democracy" ideologeme, because it established the key orientation of the opposition "ours - theirs". The Soviet political myth was rapidly collapsing due to its functioning in the post-Soviet discourse. Thus, the semantics of the word "Democracy" has undergone the change, having received a new connotation - the opposition of the Central Committee of the CPSU and the symbol of liberation. In our view a bright reference of this group of ideologemes towards an ideal future, demonstrates their key role in the development of the post-Soviet myth at the stage under consideration.

\section{Summary}

The change of political discourse in the early 1990-ies was followed by the process of new central ideologemes rethinking and creation, which became the nucleus of the emerging mythologies. The results of the study (assuming the study of the emerging ideological system in dynamics in the long term) can be applied for 
further theoretical understanding of the post-Soviet political myth development phenomenon.

\section{Acknowledgements}

The work is performed according to the Russian Government Program of Competitive Growth of Kazan Federal University.

\section{References}

[1] Budaev, E.V., Chudinov, A.P. (2008). Linguistic post sovetology. Political linguistics. Issue 2 (25). Ekaterinburg. pp. 10-19.

[2] Vepreva, I.T., Shadrina, T.A. (2006). Ideologeme and mythologeme: interpretation of terms. Scientific works of professors from Ural Institute of Economics, Management and Law. No.3, pp. 120-131.

[3] Harkova, E.V., Shigapova, F.F. (2014). Functional features of metaphoric and metonymic euphemisms in media discourse. European Journal of Science and Theology. Vol.10. No.6, pp. 105-113.

[4] Sheigal, E. (2000). Political discourse semiotics. Moscow-Volgograd: Peremena, 440 pp.

[5] Shemshurenko, O.V., Shafigullina, L.S. (2015). Politically correct euphemisms in mass media (based on American and Turkish online periodicals of the beginning of the 21st century). Journal of Sustainable Development. Vol.8. Iss.5, pp. 128-135.

[6] Van Dijk, T.A. (1998). Opinions and Ideologies in the press. In A.Bell and P.Garrett (eds), Media Discourse. Oxford: Blackwell, pp. 21-64.

[7] Wodak, R. (ed.) (1989). Language, Power and Ideology: Studies in Political Discourse. Amsterdam: John Benjamins, XX, 288 p.

[8] Dunn, J. (1995). The transformation of Russian from a language of the Soviet type to a language of the Western type. In J. Dunn (ed.), Language and Society in Post-Communist Europe. Selected Papers from the 5th World Congress of Central and Eastern European Studies. Warsaw, pp. 3-22.

[9] Koteyko N. (2014). Language and Politics in postSoviet Russia: A Corpus Assisted Approach. London: Palgrave Macmillan, XI, $191 \mathrm{p}$.

[10] Political Discourse in Transition in Europe 19891991 (1998). Ed. by Paul A.Chilton, Mikhail V.Ilyin, and Jacob L.Mey. Amsterdam: John Benjamins, X, 272 p.

[11] Ryazanova-Clarke, L. (2008). Re-creation of the nation: Orthodox and heterodox discourses in postSoviet Russia. Scando-Slavica. Vol. 54, pp. 223-239.

[12] Shaposhnikov, V. (1998). Russian speech of 1990ies. (Contemporary Russia in linguistic representation). Moscow: MALP, 248 p.

[13] Erol, N. (1993). Ideology as political discourse: a case study of print media discourses on Glasnost and Perestroika. East Lansing: Michigan State University.

[14] Guseinov, G. (2003). DSP: Soviet ideologemes in Russian discourse of the 1990-ies. Moscow: Three squares, $272 \mathrm{p}$.
[15] Malysheva, E.G. (2009). Ideologeme as linguistic cognitive phenomenon: definition and classification. Political linguistics. No.4 (30), pp. 32-40.

[16] Robinson, N. (1995). Ideology and the collapse of the Soviet system. A critical history of Soviet ideological discourse. Aldershot: Edward Elgar, X, 227 p.

[17] Izvestia (1992). Iss. 1-281.

[18] Nakhimova, E.A. (2011). The ideologeme "Stalin" in modern mass communication. Political linguistics. No.2 (36), pp. 152-156.

[19] Klushina, N.I. (2014). Theory of ideologemes. Political linguistics. No.4 (50), pp. 54-58.

[20] Zhuravlev, S.A. (2004). Ideologemes and their actualization in Russian lexicographic discourse: dis. from the cand. of philology. Yoshkar-Ola, 203 p.

[21] Schuklina, T.Y. (2014). Binary oppositions as a way of representing the Slavic culture (in the context of the Russian proverbs). Life Science Journal. Vol. 11, No.10, pp. 638-641. 